\title{
Reflections on simulated learning experiences of occupational therapy students in a clinical skills unit at an institution of higher learning
}

\author{
Santie van Vuuren, B OT (US), M OT (UFS), PhD HPE (UFS) \\ School for Allied Health Professions, Faculty of Health Sciences, University of the Free State, Bloemfontein, South Africa
}

Background: Global and national changes in healthcare create challenges in providing suitable and quality fieldwork placements for the skills training of undergraduate health professions students. The department of occupational therapy (OT) at a Higher Education Institute (HEI) in South Africa decided in 2013 to incorporate simulated learning experiences as part of the new curriculum for secondyear occupational therapy students. Two staff members of the Department of OT trained by an international institution of higher education in the use of simulation during teaching were involved. The aim of this study was to explore and describe the experiences of those students who had benefitted from simulated learning in the Clinical Skills Unit (CSU) to improve on this method of obtaining clinical assessment skills.

Methods: A qualitative methodology was used to describe the reflections of the second-year occupational therapy students of the years 2013 and 2014 (8I students) on the simulated learning of assessment procedures which took place in the CSU.

Results: Four themes and ten sub-themes were identified from the content analysis of the reflections, namely (i) personal experience (personal emotions, initial stress, confidence) (ii) Teaching and Learning clinical assessment skills (communication, occupational performance components [OPC] and occupational performance activities [OPA]); (iii) professional skills (therapeutic use of self, cooperative learning) and (iv) benefits and challenges of presenting simulated learning experiences (benefits, criticisms).

Conclusions: Occupational therapy students reported a positive experience and satisfaction with learning from the simulated experiences, which succeeded in creating a "safe" learning environment for them and opportunities to hone their clinical assessment skills prior to their first clinical fieldwork placement. Challenges associated with simulated learning experiences (SLE) were found to be: the need for clearer instructions; the number of assessments covered and the provision of a time frame to complete each task. There was consensual agreement in the department that SLE in the CSU will supplement fieldwork placements and contribute to attainment of assessment skills prior to fieldwork placements. It is recommended that current occupational therapy lecturing staff, trained in the use of simulation techniques, develop a manual for the planning of SLE and present training sessions to other staff. The manual may also be of value to other institutions of higher learning in South Africa.

Keywords: Simulated learning experiences, clinical skills learning, undergraduate education

\section{INTRODUCTION AND REVIEW OF THE LITERATURE}

Simulated learning experiences (SLE) in clinical skills units (CSUs) help to reduce anxiety in students prior to patient handling'. In addition it allows students to benefit from structured learning, supervision and feedback which take place within the context of the CSU'. SLE as used in CSUs, makes use of different modalities, such as paper case studies, role play and standardised patients [a layperson hired and trained to portray the actual patient role] that imitate real-life situations. Literature also postulates that sessions in a CSU help to bridge the gap between theory and practice $^{2,3}$, as well as enhancing self-directed learning ${ }^{4}$. While there are numerous research reports on teaching and learning innovations within $\mathrm{CSUs}^{1-4}$, the majority reports only briefly on the students' and tutors' views of the teaching and learning experiences ${ }^{5}$. Literature on occupational therapy student opinions of SLE is limited.

Weller et $\mathrm{al}^{6}$ and Coon et $\mathrm{al}^{7}$ reported on factors that set the tone for SLE within a CSU, for example the nature of clinical placements and secondly, certain educational imperatives, such as repeating sessions so that learning can be consolidated and to ensure that students have a degree of clinical competence before exposure to real patients.

Internationally, changes in healthcare, innovations in teaching and learning, technological advancement in equipment and an increase in student numbers pose challenges in providing suit- able and quality fieldwork placements ${ }^{6}$. Additionally, reducing the workload of clinical supervisors and ensuring patients' safety during the fieldwork placements of students are also a concern ${ }^{8,9}$.

The challenges related to clinical placements and clinical supervision in the training of occupational therapy (OT) students in South Africa are a reality for institutions of higher learning. Financial constraints in the health sector and vacancies that cannot be filled in many instances, lead to a shortage of clinical supervisors to guide students ${ }^{10}$. Other constraints include the lack of equipment to practise skills and the availability of a range of health problems needed to enable all students to have similar fieldwork experiences to fulfil the course requirements" ${ }^{\prime \prime}$.

According to Rodger et al $^{12}$, SLE is increasingly being used as a means of augmenting and sometimes supplementing aspects of clinical rotations. These simulated experiences can provide authentic learning in a safe environment for skills such as communication and teamwork ", interviewing, physical examination and counselling that are vital to effective patient care ${ }^{13,14}$. Rodger et $\mathrm{a}^{12}$ added that a SLE can also be designed so that professional behaviour such as occupation-focussed language and managing ethical dilemmas can be practised. Holmboe ${ }^{14}$ stated that the most effective assessment of these skills is by direct observation of all students performing these skills and that direct observation is most easily achieved during an SLE in a CSU. However, Freeth $^{5}$ and Weller et $\mathrm{al}^{6}$ warned that an SLE cannot replace direct observation of the student working with actual patients.

From the viewpoint of student experiences, Rutherford- 
Hemming ${ }^{9}$ further noted that learning in a simulated environment had an effect on transfer of learning in clinical skill acquisition. Studies on simulated learning experiences by Jacobs and Venter ${ }^{15}$ and Knecht-Sabres" reported that there was an increase in confidence and better integration of theory and skills. Laschinger et al ${ }^{16}$ added that students experienced a higher level of satisfaction when using simulations to learn clinical skills. Coon et $\mathrm{al}^{7}$ reported that students who participated in simulated learning in addition to standard learning performed equally or better than those who participated in standard learning alone when the results of practical examinations were evaluated. However, in a study by Giesbrecht et $\mathrm{al}^{17}$ in which peers were used to role play because it was more pragmatic and cost-effective, students identified this as an undesirable option due to the lack of authenticity. In most of the studies on SLE's published, fieldwork supervisors and students exposed to simulated learning experiences reported being more client-focussed, independent and able to work collaboratively ${ }^{11,15,16}$.

With respect to innovative learning strategies, such as SLE, a CSU has the potential to provide greater efficiency and rigour compared with learning through opportunistic clinical experiences $^{6}$.

The fieldwork guideline for the training of occupational therapists set by the World Federation of Occupational Therapists (WFOT) ${ }^{18}$ states that simulated learning experiences (SLE) can be used prior to, during, or following clinical placements. The report of Rodger et $\mathrm{al}^{12}$ on the planning and implementation of SLEs states that $20 \%$ of the 1000 clinical hours required by the WFOT can be delivered by means of simulated learning experiences.

Globally, limited research has been published on the use of SLE during the training of occupational therapists. A survey ${ }^{19}$ of 12 occupational therapy schools in America found that simulated modalities were mostly used in the first two years of their programmes. In this survey most of the participants recognised and valued any opportunity to enhance skill development and practise skills with simulation prior to fieldwork placement. Students also preferred simulation/video/guest visits to lecture format and book learning, but "preferred contact in the real world to simulation if given the option"19(p|9).

Feedback from students at the University of Queensland ${ }^{12}$ concurs with findings of other health science students such as "it was practical and related directly to OT, which I love about it" and "it makes you more confident to interact with patients; I prefer standardized patients to role play because you have to take it seriously" 12:33. In the report of the National Health Workforce of Australia (NHWF) of 20I0, one of the recommendations was that research about the effectiveness and implementation of simulated learning activities should be funded ${ }^{12}$. No information has yet been published on the SLE of South African occupational therapy students.

In view of the challenges of accommodating, especially firstand second-year students in clinical fieldwork settings, by reason of the students' inexperience, the expectations of the supervisory role and the availability of clinical placements [due to the lack of and the filling of public sector posts] ${ }^{10}$ new strategies for training were necessary. As part of the review of the second-year curriculum in the Department of Occupational Therapy, the positive research results of simulated learning experiences found internationally and the availability of a clinical skills unit in the department it was decided to incorporate simulated experiences to teach assessment skills from 2013 onwards $^{20}$. The simulated learning experience on assessment was organised in the CSU, using standardised patients who were members of the community representing different age groups. Students were informed beforehand of the simulation session, that they will be grouped in two's and what assessment skills to prepare. The results of this research will guide the future planning and value of simulated clinical assessment procedures in the second year OT curriculum.

\section{METHODS}

\section{Aim of the study}

This study aimed to explore and describe the perceptions and learning experiences of simulated clinical assessment procedures among the second year occupational therapy students in the years 2013 and 2014.

\section{Research design}

The research design was of an explorative descriptive qualitative nature. A retrospective audit of the students' written reflections was done after the simulated learning had taken place. The strength of using a retrospective database (in this study, the written reflections of students) was that it allowed the researcher to examine a larger study population, and provided a relatively inexpensive and pragmatic approach for answering research questions ${ }^{21,22}$.

\section{Study population}

The population included the $8 \mathrm{I}$ second-year occupational therapy students' (20I3n=38; $2014 n=43)$. These students' learning of simulated assessment skills was scheduled during the first block of Module OCTC 2704 (Clinical Fieldwork). The focus of this SLE was to train the student in the assessment of occupational therapy components as well as occupational therapy activities in a safe environment under the supervision of teaching staff the outcome being the application of these assessment skills. The students were required to write anonymous reflections of their experiences during the SLE directly after the session and hand it in. The reflections of all of the $8 \mathrm{I}$ students were included in the analysis

\section{Ethics}

After approval to conduct the study had been obtained from the relevant authorities, including the Ethics Committee of the Faculty of Health Sciences, University of the Free State, written consent was obtained from all students for the use of the reflections written as part of the evaluation of the block.

\section{Data collection and analysis}

A retrospective audit using inductive reasoning was applied to identify themes and sub-themes in the student reflections on the SLE. In this study, the researcher was personally involved in the research and used her understanding and experience of simulated learning to conduct this audit. A senior colleague familiar with the context of the revised occupational therapy curriculum independently coded the students' reflections. Consensus on the results was reached between the researcher and co-coder on the themes and sub-themes. Rules for the coding of texts were developed and decisions were made on dealing with irrelevant information in the reflections by working back and forth between the themes and data to reach consensus on the themes and sub-themes ${ }^{22}$. The institution follows a language policy that accommodates both English- and Afrikaans- speaking students.

Credibility was established by making use of a purposeful sample, recording a precise description of each part of the research process and the process undertaken during analysis that made it possible to replicate the study. Conformability was established by comparing information of categories and themes and discussing differences. The literature review conducted was used as a control for identifying and reach consensus on the similarities.

\section{RESULTS}

Thirty-eight second-year students handed in their reflections after the SLE sessions in 2013 and 43 students in 2014. Four themes and 10 sub-themes emerged from the content analysis of the reflections: (i) personal emotions; (ii) initial stress; (iii) confidence; (iv) communication skills; ( $v$ ) assessment skills of occupational performance areas; (vi) occupational performance activities; (vii) therapeutic use of self; (viii) co-operative learning; and (ix) benefits and (x) challenges of teaching and learning in a simulated learning environment (See Table I on page 82). 
Table I: Examples of student responses categorised per theme

\begin{tabular}{|c|c|c|}
\hline Themes & Sub-Themes & Examples of students' remarks \\
\hline I. Personal experience & $\begin{array}{l}\text { Personal emotions } \\
\text { Initial stress } \\
\text { Confidence }\end{array}$ & $\begin{array}{l}\text { - It was amasing how fear can turn into excitement. } \\
\text { - Makes me excited about Occupational Therapy and all that we can achieve. } \\
\text { - Anxious before the session. } \\
\text { - I was so nervous before today. } \\
\text { - Onervare/lnexperienced. } \\
\text { - Getting practical experience makes me feel more confident. } \\
\text { - Improved my confidence. }\end{array}$ \\
\hline $\begin{array}{l}\text { 2. Teaching and learning } \\
\text { Clinical assessment skills }\end{array}$ & $\begin{array}{l}\text { Occupational performance } \\
\text { areas (OPCs) } \\
\begin{array}{l}\text { Occupational performance } \\
\text { activities (OPAs) }\end{array}\end{array}$ & $\begin{array}{l}\text { - Hoe om professioneel op te tree/How to act professionally. } \\
\text { - I realized that in order to get the most valuable information I have to } \\
\text { engage with the patient. } \\
\text { - Unsure about what questions to ask. } \\
\text { - I learnt that I am actually comfortable with speaking to people. } \\
\text { - Weet nou wat om in die toekoms te verwag/ know now what to expect in } \\
\text { future. } \\
\text { - It is a good feeling to put theory to practise. } \\
\text { - Practise how to fill in assessment forms while with a "patient". } \\
\text { - Aangesien dit simulasie was, kon ek seker maak dat ek reg werk/Because it } \\
\text { - Mas simulation I could ensure that I work correctly. } \\
\text { het/One can assess more from observation and the interview than I } \\
\text { thought. } \\
\text { - Everything does not always go as planned. }\end{array}$ \\
\hline 3. Professional skills & $\begin{array}{l}\text { Therapeutic use of self } \\
\text { Co-operative learning }\end{array}$ & $\begin{array}{l}\text { - I constantly evaluated myself and had thoughts such as: Am I doing it right? } \\
\text { - Enjoyed practical hands-on experience - practise makes perfect. } \\
\text { - Toekoms beter voorberei/Better prepared in future. } \\
\text { - How to handle patients with care. } \\
\text { - Nie altyd die pasient probeer gelukkig hou nie ... julle tyd saam orden en } \\
\text { struktureer/Not always try to keep the patient happy ...time together must } \\
\text { be organised and structured. } \\
\text { - How to adapt. } \\
\text { - Felt better doing it in pairs; it lowered my stress levels. } \\
\text { - Working in pairs helped to learn from my partner. } \\
\text { - I felt most engaged. } \\
\text { - It was nice to observe other groups as well. }\end{array}$ \\
\hline $\begin{array}{l}\text { 4. Benefits and challenges } \\
\text { of presenting SLE }\end{array}$ & Benefits & $\begin{array}{l}\text { - Dit het gehelp dat daar genoeg dosente was wat ons gehelp het/lt helped } \\
\text { that there were enough lecturers to assist us. } \\
\text { - Suggestion - to have many more of these because we got a chance to apply } \\
\text { the knowledge we have to "real life situations". } \\
\text { - Next time clearer instructions. } \\
\text { - I did feel overwhelmed by the amount of things we had to assess. } \\
\text { - A time frame for the completion of each task. } \\
\text { - Like to get feedback straight after doing the assessment. }\end{array}$ \\
\hline
\end{tabular}

\section{DISCUSSION}

The aim of the study was to describe the second year OT students' reflections of simulated learning of assessment techniques. The results indicate that students were generally satisfied with the SLE as part of the teaching of assessment skills before fieldwork rotations $^{5,12,15,23}$, although some criticisms were raised in the students' reflections.

Millens et $\mathrm{al}^{24}$ recommend that sound design of the simulation programme is essential. Baptiste and Solomon ${ }^{25}$ also report, that there appears to be a strong willingness of the occupational therapy students to invest personally in the simulated learning experience. Velde et $\mathrm{al}^{19}$ identified a desire among occupational therapy students for inclusion of simulated patients early in their curriculum. This supports the decision made by the occupational therapy department where the SLE is initiated in the second year of study ${ }^{20}$. Although the value of simulated learning has been well researched, more research on this topic is needed ${ }^{17}$ to determine the effectiveness for occupational therapy students as it seems that they value this learning experience.

The personal emotions experienced by the students during the simulated learning experience in this study varied from being anxious to fear turning into excitement and enjoyment. This finding is supported by Jacobs et al ${ }^{15}$ and Botma ${ }^{23: 3}$ who stated that "although students were apprehensive and felt scared at first, the overwhelming outcome of the simulated learning experience is that of having fun while learning." Most of the stress was before or at the start of the learning experience and more confidence was gained as the experience progressed. It seems that as they gained confidence they felt more in control.

In terms of communication skills during a clinical assessment, the value of the simulated experience so early in the training programme (second year) is that it allows students to practise introspection of their own feelings while working with and communicating with "patients". One student reported: I realised that in order to get the 
most valuable information I have to engage with the patient. This concurs with the findings of Knecht-Sabre " that a clinical skills unit is a safe learning environment in which educators can guide and support students before the students enter their clinical fieldwork.

The majority of students indicated that the simulated experiences prepared them to communicate and act professionally during the assessment of a real patient ${ }^{6,7}$. They found that it resulted in the realisation of the importance of listening skills, being professional and the challenges that language might pose during communication. Jacobs et $\mathrm{al}^{15}$ also reported that the importance of being an active listener could be elicited when using a simulated experience, as one student reflected: "I realised that in order to get the most valuable information I have to engage with the patient".

They also saw it as an opportunity to put the theory of assessment of OPC and OPA into practice in a safe environment with another student and under the supervision of their lecturers. They experienced the SLE as a practise opportunity to understand some of the expectations and responsibilities during fieldwork rotations. Aangesien dit simulasie was, kon ek seker maak dat ek reg werk/ because it was simulation I could ensure that I worked correctly and that everything does not always go as planned. These sentiments are supported by Botma ${ }^{23}$ and $\mathrm{Hill}^{13}$ who describe simulation as a vehicle for translating classroom knowledge into a safe "clinical" learning environment. Although not mentioned by the students in this study, according to the students in the study by Velde et al, "feeling secure is fundamental to the learning process ${ }^{19:}$ e-20. Students prefer "contact in the real world" to classroom teaching ${ }^{17}$. In this study students reflected on their professional experiences as follows: In die toekoms beter voorberei/be better prepared in future; learned how to handle patients with care. Treadwell et $\mathrm{a}^{26}$ agree that students needed to plan in advance and they needed to be knowledgeable about the standards and basics of performing procedures.

Other skills needed for clinical fieldwork such as teamwork were also reflected upon: Working together with a peer was viewed by most students as positive and also that it reduced their anxiety. Working in pairs helped to learn from my partner. They also perceived that co-operative learning contributed to helping one another and helped them to learn how to handle the patients. The value of cooperative learning is emphasised by Strand ${ }^{27: 20}$ who reports: "both dialogue, which might foster understanding of the subject matter and disagreement that could aid students in reflecting on their mistakes should be considered." This concept is supported by Ker et $\mathrm{a}^{28}$ and Bakhtin ${ }^{29}$.

In the opinion of the students some of the criticisms that may pose a challenge for the occupational therapy department using SLE are: I did feel overwhelmed by the amount of things we had to assess; like to get feedback straight after doing the assessment and a time frame for the completion of each task. Interestingly, in a study by Griesbrecht ${ }^{17}$ occupational therapy students placed a higher value on simulation patients' feedback than educator feedback. They appeared to derive a better sense of success that would enable them to cope with real patients in the clinical setting. In this study no comments were made about the simulation patients' feedback, but rather on the importance of enough educators to give feedback. The age difference between the study groups might have played play a role, as most students in our study were 20 years of age, compared to the study mentioned before, in which the mean age was 26.3 years $^{21}$.

As the study population consisted of only the second year students' reflections, it is unclear to what extent the responses of the participants of this audit could be generalised to other simulated clinical learning experiences due to the adeptness to reflect. The age of the participants may have meant that some of the participants might not have taken the reflections serious, or might have lacked the ability to reflect or the effort or willingness to invest in in depth reflection ${ }^{15}$. In this study, the researcher acted as a human instrument and could have had an influence on the direction the research took during the audit.

\section{CONCLUSION}

Finally the results demonstrated that while the majority of students is positive towards simulated learning experiences there are aspects in the presentation of the learning experience that should be considered. The criticisms were related to a lack of time in skills training and specific information on what to expect in the simulated assessment training.

Holmboe ${ }^{14}$ states that skills with regard to interviewing and physical examination (assessment) remain vital to effective patient care, yet research continues to document serious deficiencies in clinical skills among students. He however maintains that health educators must not relinquish the responsibility of skills training through simulating patients and simulation alone. Rather, such approaches should complement teaching and learning ${ }^{14}$, which concurs with the opinion of Millens et $\mathrm{al}^{24}$.

The researcher is of the opinion that simulated learning experiences have a definite place in teaching skills to occupational therapy students. An added value, although not part of the aim of this study, may be the researcher's observation on the ability of students to reflect, as reflection has become an integral part of student learning and continuous development as a professional.

\section{POTENTIAL VALUE OF THE RESEARCH}

Results of this audit were communicated to the curriculum committee of the Department of Occupational Therapy to be taken into consideration during its evaluation of the second-year curriculum. The strengths and weaknesses of the clinical simulation activities used can be identified and decisions on changes can be informed and implemented in future to improve the use of simulated learning. Staff that was trained by an International Institution in the use of simulated learning experiences can develop a manual to assist other staff in the Department to plan these learning experiences. Furthermore, the utilisation of simulated learning experiences can also be discussed on a national level to strategise on combining the resources of the different training centres.

\section{ACKNOWLEDGEMENTS}

Dr. Daleen Struwig, Faculty of Health Sciences, University of the Free State, for technical support.

\section{REFERENCES}

I. Peterson MJ, Bechtel GA. Combining the arts: an applied critical thinking approach in the skills laboratory. Nursing Connections, 2000; 13(2): 43-49.

2. Whait I, Allen R, Jones V. A portfolio approach. In: Glenn S, Nicol $\mathrm{M}$, eds. Clinical skills in nursing: the return to the practical room? Basingstoke: Macmillian; 1999: 65-8I.

3. Jeffries PR, Rew S, Cramer JM. A comparison of student-centred versus traditional methods of teaching basic nursing skills learning. Nursing Education Perspective, 2002; 23(I): 14-19.

4. Nestel D, Kneebone R, Kidd J. Teaching and learning about skills in minor surgery. Journal of Clinical Nursing, 2003; I2(2): 29|-296.

5. Freeth $D$, Fry H. Nursing students' and lecturers' perceptions of learning and teaching in clinical skills center. Nurse Education Today, 2005; 25(4): 272-278.

6. Weller JM, Nestel D, Marshall SD, Brooks PM, Conn JJ. Simulation in clinical teaching and learning. Medical Journal of Australia, 2012; 196(9): 594.

7. Coon E, Khoramshaki C, Popoff M. Simulated learning for occupational therapy and physiotherapy students. Waterloo, ON: Knowledge Impact Strategies Consulting Ltd; I- 19. www.kimpact. ca (accessed $31 / 08 / 14)$.

8. Ciccarelli, M. Using mastery learning to develop patient handling skills in occupational therapy students. International Journal of Therapy and Rehabilitation, 2005; 12(7): 287-293.

9. Rutherford-Hemming T. Learning in simulated environments: effects on learning transfer and clinical skill acquisition in nurse practitioner students. Journal of Nursing Education, 2012; 5 I (7): 403-406.

10. Cole J. Structural analysis of rehabilitation and human resource need and supply of health therapists in SA. SA Committee of Health Sci- 
ences Deans; 2012 [unpublished report].

II. Knecht-Sabres LJ. Preparing occupational therapy students for the complexities of clinical practice. Open Journal of Occupational Therapy, 2013; I(3); article 4. http://scholarworks.wmich.edu/cgi/ viewcontent.cgi?article $=1047 \&$ context $=$ ojoccupational therapy (accessed 26 July 20I4). I2. Roger S, Bennett S.

12. Rodger, S., Bennet, S., Fitzgerald C, Neads, P. Use of simulated learning activities in occupational therapy curriculum. Final report. Melbourne: University of Queensland and Health Workforce Australia; 20I0. https://www.hwa.gov.au/sites/default/files/simulatedlearning-in-occupational-therapy-curricula-20 I 108.pdf (accessed 20 February 2015).

13. Hill R, Nestel D, French J. Promoting transfer of clinical skills from simulation to hospital settings: the role of clinical nurse educators in medical education. International Journal of Clinical Skills, 201 I; 5(2): 77-82.

14. Holmboe ES. Faculty and the observation of trainees' clinical skills: problems and opportunities. Academic Medicine, 2004; 70(I): I6-22.

15. Jacobs AC, Venter I. Standardized patient: simulated practice learning applied to psychiatric nursing. Faculty of Health Sciences Annual Research Forum. Bloemfontein: University of the Free State; 2013 [unpublished].

16. Laschinger S, Medves J, Pulling C, McGraw R, Waytuck MLS, Harrison M, Gambeta K. Effectiveness of simulation on health profession students' knowledge, skills, confidence and satisfaction. International Journal of Evidence Based Health, 2008; 6(3): 278-302.

17. Giesbrecht EM, Wener PF, Pereira GM. A mixed methods study of student's perceptions of using standardized patients for learning and evaluation. Advances in Medical Education Practice, 20 I4; 5: 24I-255.

18. 'World Federation of Occupational Therapists (WFOT). Revised minimum standards for education of occupational therapists. Fieldwork Guidelines. 2002. www.qoccupationaltherapyfc.edu.au/ resource/index.html?page $=65348$. (Accessed 2 November 2014).

19. Van Velde B.P, Lane H, Clay M. Hands-on learning: the use of simulated clients in intervention cases. Journal of Allied Health, 2009; 38(I): EI7-2I.

20. Van Vuuren S. Adapted clinical fieldwork cycle of second-year Occupational Therapy students. Bloemfontein: Department of Occupational Therapy, University of the Free State; 2013 [unpublished].

21. Motheral B, Brooks J, Clark M, Crown WH, Davey P, Hutchins D, Martin BC, Stang P. A checklist for retrospective database studies report of the ISPOR Task Force on Retrospective Databases. Value Health, 2003; 6(2): 90-97.

22. Creswell JW. Research design. Qualitative and mixed methods approaches. $3^{\text {rd }}$ ed. London: Sage; 2009.

23. Botma Y. Nursing student's perceptions on how immersive simulation promotes theory - practice integration. International Journal of Africa Nursing Science, 20 I4; I: I-5.

24. Millens L, Moore C, Spren J. Simulation-based education. New South Wales: Health Education Training Institute; 2014.

25. Baptiste S, Soloman P. Developing communication skills. Innovations in rehabilitation sciences education: preparing leaders for the future. Berlin: Springer Verlag; 2005: I 36- I 45.

26. Treadwell I, Grobler S. Student's perceptions on skills training in simulation. Medical Teacher, 200 I; 23(5): 476-482.

27. Strand, I., Nåden $D$, Slettebø A. Students learning in a skills laboratory. Vård I Norden, 2009; 93(29): I8-22.

28. Ker J, Mole L, Bradley P. Early introduction to interprofessional learning: a simulated ward environment. Medical Education, 2003; 37(3): 248-255.

29. Bakhtin, M. Latter og dialog: utvalgte skrifter [Laughter and dialogue: selected texts]. (Translated by Morch AJ). Oslo: Cappelen Akademisk; 2003. 